\title{
The Role of Soil Microbes in Plant Nutrient Availability
}

\author{
Preeti Singh $^{1}$, Seema ${ }^{1 *}$, S. P. Goswami ${ }^{1}$, Sunita Choudhary ${ }^{2}$ and Sunil Kumar ${ }^{2}$ \\ ${ }^{1}$ Department of Soil Science and Agricultural Chemistry, Institute of Agricultural Sciences, \\ Banaras Hindu University, Varanasi-221005, India \\ ${ }^{2}$ Department of Agronomy, Institute of Agricultural Sciences, BHU Varanasi - 2210 05, India \\ *Corresponding author
}

\section{A B S T R A C T}

\section{Keywords}

Mycorrhizal fungi, Microbial inoculums, Plant growth promoting rhizobacteria.

Article Info

Accepted:

24 January 2017

Available Online:

10 February 2017
It is likely to provide plants with their necessary nutrients using chemical and biological fertilization. Although chemical fertilization is a quick method, it is not recommendable economically and environmentally, especially if overused. Biological fertilization is the use of soil microbes including arbuscular mycorrhizal fungi and plant growth promoting rhizobacteria to inoculate plants. It has been proved that biological fertilization is an efficient method to supply plants with their necessary nutrients. It is economically and environmentally recommendable, because it results in sustainability. In this article, some of the most important details including the mechanisms and processes regarding the effects of soil microbes on the availability and hence uptakes of nutrients by plant are reviewed. Such details can be important for the selection and hence production of microbial inoculums, which are appropriate for biological fertilization.

\section{Introduction}

Sustainable crop production is essential to a healthy and adequate food supply. At first glance, a healthy crop reveals only the above ground plant; the roots that support the visible plant are seldom seen. But these plant roots grow in an incredibly complex environment, teeming with billions of soil organisms, particularly bacteria and fungi, which play a crucial role in promoting root health and maintaining an adequate supply of plant nutrients for crop growth. It has long been observed that plants conspicuously modify their soil environment by exuding large amounts of carbon from their roots. This rhizosphere zone becomes a biological hotspot in the soil. Adding carbon to the soil surrounding the roots leads to a huge increase in the number of microorganisms living within and outside the roots. These root exudates are composed of a complex mixture of low-molecular weight compounds such as amino acids, organic acids, sugars, and phenolics.

Root mucilage, a carbon-rich gel layer surrounding the root tip, also provides a complex mixture of sugars, proteins, and enzymes to rhizosphere organisms. In some plants, as much as one-third to one-half of all the total carbon assimilated by photosynthesis can be transferred to the soil through the roots (Kuzyakov and Domanski, 2000). 
Living organisms have a crucial role in controlling the transformations of plant nutrients in soil. In most soils, N, P and S are mainly present as various organic compounds that are unavailable for plant uptake. Understanding the role of microorganisms in regulating the conversion of these organic pools into plant-available forms has received considerable attention from soil scientists and agronomists.

The microbial conversion of nutrients into a soluble form takes place through numerous mechanisms. Extracellular enzymes and organic compounds can be specifically excreted to solubilize plant-available nutrients from soil organic matter, crop residues, or manures.

Better understanding the essential link between soil microbes and plant nutrient availability will allow more informed management decisions to be made for proper stewardship of soil resources and for sustaining acceptable levels of crop productivity.

\section{Nutrients are converted to plant-available forms}

In most soils, $\mathrm{N}$ and $\mathrm{P}$ are mainly present as various organic compounds that are unavailable for plant uptake. Several organic compounds (compounds containing carbon) compose the organic fraction of nitrogen in soil. Soil organic matter exists as decomposing plant and animal residues, relatively stable products of decomposition resistant compounds and humus. Nitrogen and phosphorus have accumulated in these various organic fractions during soil development. The microbial conversion of nutrients into a soluble form takes place through numerous mechanisms (Table 1).

Some of the nutrients whose availability increases by microbes-

\section{Nitrogen}

\section{Nitrogen fixation}

Fixation is the process of converting dinitrogen gas to chemically reactive forms where nitrogen combines with other elements such as oxygen, hydrogen, and carbon. The process of $\mathrm{N}$ fixation initiates with some biochemical communications between the two symbionts. Such products include flavonoids and lipochito oligosaccharides, produced by the host plant and the bacteria, respectively. Such products determine the specificity of the process of $\mathrm{N}$ fixation (Miransari and Smith 2007, 2009; Ferguson et al., 2010; Van de Velde et al., 2010). Under optimum conditions, the bacteria are able to fix significant amounts of atmospheric $\mathrm{N}$, which is of economical and ecological importance. It is because the process of $\mathrm{N}$ fixation can significantly decrease the amounts of chemicals for fertilization both under dry and humid conditions. Under humid conditions, $\mathrm{N}$ is more mobile and hence subjected to processes such as leaching and denitrification, decreasing $\mathrm{N}$ availability to the plant (Miransari and Mackenzie2011a, b; Miransari and Smith 2007, 2008, 2009). There are also soil bacteria such as Azospirillum spp., Azotobacterspp., Azoarcus spp.,cyanobacteria, Bacillus spp., Enterobacter spp., Xanthobacter spp., Gluconacetobacter diazotrophicus, Achromobacter spp., Arthrobacter spp., Azomonas spp., Clostridium spp., Beijerinckia spp., Corynebacterium spp., Rhodospirillum spp., Klebsiella,spp., Derxia, spp., Herbaspirillium spp., Pseudomonas spp., Rhodopseudomonas spp., etc., which can fix atmospheric $\mathrm{N}$ in non-symbiotic association with their host plant (Saxena and Tilak, 1998; Saharan and Nehra, 2011). AM fungi can also increase the uptake of different nutrients by their host plant through their extensive hyphal network. Although there are 
some signs indicating that AM fungi can affect the process of $\mathrm{N}$ uptake by the host plant through their extensive hyphal network and production of different compounds, the greater details have yet to be further investigated (Podile and Kishore, 2006; van Loon, 2007; Miransari, 2011b).

\section{Nitrogen mineralization}

Once nitrogen is fixed, it is subject to several chemical reactions which can convert it to different organic or inorganic forms. Mineralization occurs in soil as microorganisms convert organic nitrogen to inorganic forms. The first step of mineralization is called aminization, in which microorganisms (primarily heterotrophs) break down complex proteins to simpler amino acids, amides, and amines.

\section{Aminization: Proteins $\longrightarrow \mathrm{R}+\mathrm{NH}_{2}+\mathrm{ROH}$}

Ammonification is the second step of mineralization in which amino $\left(\mathrm{NH}_{2}\right)$ groups are converted to ammonium. Again, microorganisms (primarily autotrophic) accomplish this action.

Ammonification: $\mathrm{RNH}_{2}+\mathrm{H}_{2} \mathrm{O} \longrightarrow \mathrm{NH}_{3}+$ $\mathrm{ROH}$

Nitrification: Microbial activity is also responsible for the two steps of nitrification. Nitrosomonas (obligate autotrophic bacteria) convert ammonium to nitrite. Nitrification inhibitors, such as nitrapyrin (NServeR) or dicyandiamide (DCD), interfere with the function of these bacteria, blocking ammonium conversion to leachable nitrate. The second step of nitrification occurs through Nitrobacter species, which convert nitrite to nitrate. This step rapidly follows ammonium conversion to nitrite, and consequently nitrite concentrations are normally low in soils.
Nitrosomonas

Organic Nitrogen $\longrightarrow$ Nitrite Nitrobacter

$\longrightarrow$ Nitrate

$2 \mathrm{NH}_{4}^{+}+3 \mathrm{O}_{2} \rightarrow 2 \mathrm{NO}_{2}^{-}+2 \mathrm{H}_{2} \mathrm{O}+4 \mathrm{H}^{+}+$ $2 \mathrm{NO}_{2}+\mathrm{O}_{2} \longrightarrow 2 \mathrm{NO}_{3}$

Mineralization and nitrification are influenced by environmental factors that affect biological activity such as temperature, moisture, aeration, $\mathrm{pH}$, and so forth.

\section{Phosphorus}

Microorganisms play an important role in the acquisition and transfer of nutrients in soil.In particular, microorganisms can solubilise and mineralize $\mathrm{P}$ from inorganic and organic pools of total soil $\mathrm{P}$.

In addition, microorganisms may effectively increase the surface area of roots. Also, the microbial biomass itself contains a large pool of immobilized $\mathrm{P}$ that potentially is available to plants. Despite the widespread deficiency of plant-available $\mathrm{P}$, most soils contain large amounts of total P. Although a proportion of this $\mathrm{P}$ occurs as 'native' soil $\mathrm{P}$, in agricultural soils a significant amount has accumulated as a consequence of previous applications of $\mathrm{P}$ fertilizer, with net accumulations of approximately $10 \mathrm{~kg} \mathrm{P}$ ha $^{-1}$ year $^{-1}$ being typical for moderately fertilized soils in Australia (McLaughlin et al., 1988). This accumulated $\mathrm{P}$, like total soil $\mathrm{P}$, occurs in either organic (Po) or inorganic (Pi) forms (Sanyal and De Datta 1991).

An extensive range of soil bacteria and fungi that are able to solubilize various forms of precipitated $\mathrm{P}$ have been reported (see reviews by Kucey et al., 1989; Rodríguez and Fraga 1999; Whitelaw 2000). Predominant among these organisms are Bacillus, Pseudomonas, Penicillium and Aspergillus spp. 
Table.1 Selected examples of microbially mediated soil transformations that influence plant nutrient availability

\begin{tabular}{|l|l|}
\hline Nutrient & Microbial transformation \\
\hline Nitrogen & $\begin{array}{l}\text { Mineralization, immobilization, nitrification, denitrification, urea hydrolysis, } \\
\text { N fixation, extracellular protease and chitinase activity }\end{array}$ \\
\hline Phosphorus & $\begin{array}{l}\text { Mineralization, immobilization, extracellular phosphatase activity, acidic } \\
\text { dissolution of mineral P, facilitated uptake by mycorrhizal fungi }\end{array}$ \\
\hline Potassium & K solubilization \\
\hline
\end{tabular}

Fig.1 Schematic representation of the physiological and chemical processes that influence the availability of phosphorus in the rhizosphere (adapted from Richardson, 1994)

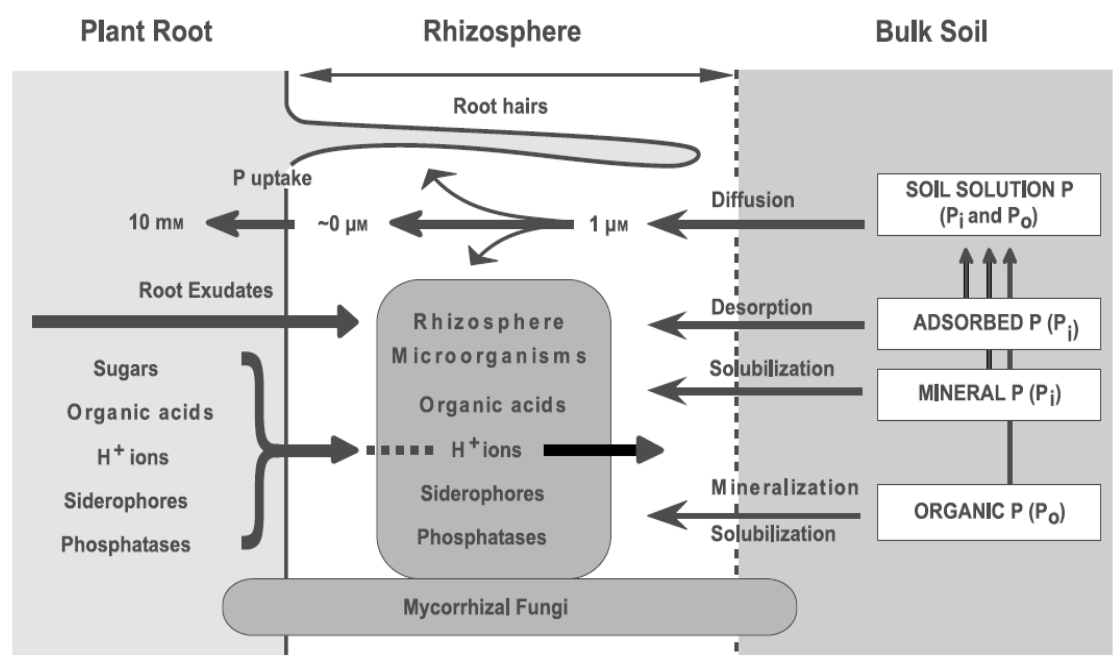

On the basis of laboratory screening assays, it has been shown that P-solubilizing microorganisms may constitute up to $40 \%$ of the culturable population of soil microorganisms and that a significant proportion of them can be isolated from rhizosphere soil (Kucey, 1983).

Furthermore, the importance of these mechanisms for $\mathrm{P}$ solubilization by microorganisms directly in soil has received limited attention. The symbiotic association between plant roots and mycorrhizal fungi has long been established as an important mechanism by which plants are able to acquire $\mathrm{P}$ (and other nutrients) from soil (Marschner and Dell, 1994; Smith and Read, 1997). Mycorrhizae are associated with either the apoplast of cortical root cells (ectomycorrhizae) or form arbuscule structures in close association with host cells (endomycorrhizae, usually termed vesiculararbuscular or VA mycorrhizae. PGPR has also been indicated to be affective on the enhancement of $\mathrm{P}$ availability in the soil. For example, such bacteria are able to produce enzymes (phosphatases) (at less amounts compared with plants) and products such as organic products such as organic acids (carboxylic acids), protons, etc., which can increase $\mathrm{P}$ availability in the soil by affecting the mineral $\mathrm{P}$ sources such as rock phosphate. The source of $\mathrm{P}$ (organic or mineral), host plant, microbial combination, $\mathrm{pH}$, anions and cations, etc. determine P solubility in the soil (Houser and Richardson 2010; Niu et al., 2010; Salimpour et al., 2010) (Fig. 1). 


\section{Potassium}

Potassium is the third essential nutrient required by plants. Potassium solublising microorganisms play vital role in making available insoluble forms of potassium by mineralization. They solublise potassium from insoluble forms like mica, feldspar and others by producing organic acids, siderophores and also capsular polysaccharides. In a study it was reported that potassium soluiblizing bacteria $B$. mucilaginosus are able to soluiblize rock $\mathrm{K}$ mineral powder such as micas, illite and orthoclases through production and excretion of organic acids (Ullaman, 1996). Another report showed that potassium was soluiblized by production of inorganic and organic acids and due to production of mucilaginous capsules containing of exopolysaccharides by Bacillus, Clostridium and Thiobacillus (Groudev, 1987).

\section{References}

Ferguson, B.J., Indrasumunar, A., Hayashi, S., Lin, M.H., Lin, Y.H., Reid, D.E., Gresshoff, P.M. 2010. Molecular analysis of legume nodule development and autoregulation. $J$. Integr. Plant Biol., 52: 61-76.

Groudev, S.N. 1987. Use of heterotrophic micro-organisms in mineral biotechnology. Acta Biotechnol., 7; 299-306.

Houser, J., Richardson, W. 2010. Nitrogen and phosphorus in the Upper Mississippi River: transport, processing, and effects on the river ecosystem. Hydrobiologia, 640: 7188

Hu, X.F., Chen, J. and Guo, J.F. 2006. Two phosphate and potassium solubilizing bacterial isolated from Tiannu Mountain, Zhijiang, China. World J. Microbiol. Biotechnol., 22: 983-990.
Kucey, R.M.N. 1983. Phosphate-solubilizing bacteria and fungi in various cultivated and virgin Alberta soils. Can. J. Soil Sci., 63: 671-678.

Kucey, R.M.N., Jansen, H.H., Leggett, M.E. 1989. Microbially mediated increases in plant-available phosphorus. $A d v$. Agron., 42: 199-228

Marschner, H., Dell, B. 1994. Nutrient uptake in mycorrhizal symbiosis. Plant Soil, 159: 89-102.

McLaughlin, M.J., Alston, A.M., Martin, J.K. 1988. Phosphorus cycling in wheatpasture rotations. II. The role of the microbial biomass in phosphorus cycling. Australian J. Soil Res., 26: 333-342.

Miransari, M,. Smith, D. 2008. Using signal molecule genistein to alleviate the stress of suboptimal root zone temperature on soybeanBradyrhizobium symbiosis under different soil textures. J. Plant Interact, 3: 287-295.

Miransari, M. 2011a. Arbuscular mycorrhizal fungi and nitrogen uptake. Arch. Microbiol., 193: 77-81.

Miransari, M., Balakrishnan, P., Smith, D.L., Mackenzie, A.F., Bahrami, H.A., Malakouti, M.J., Rejali, F. 2006. Overcoming the stressful effect of low $\mathrm{pH}$ on soybean root hair curling using lipochitooligosaccahrides. Commun. Soil Sci. Plant Anal., 37: 1103-1110.

Miransari, M., Mackenzie, A.F. 2011 b. Development of a soil $\mathrm{N}$ test for fertilizer requirements for wheat. $J$. Plant Nutr., 34: 762-777.

Miransari, M., Smith, D.L. 2007. Overcoming the stressful effects of salinity and acidity on soybean nodulation and yields using signal molecule genistein under field conditions. J. Plant Nutr., 30: 19671992. 
Miransari, M., Smith, D.L. 2009. Alleviating salt stress on soybean. Glycine max. L.. Merr.)—Bradyrhizobium japonicum symbiosis, using signal molecule genistein. Eur. J. Soil Biol., 45: 146-152.

Niu, S., Wu, M., Han, Y.I., Xia, J., Zhang, Z., Yang, H., Wan, S. 2010. Nitrogen effects on net ecosystem carbon exchange in a temperate steppe. Glob. Change Biol., 16: 144-155

Podile, A., Kishore, G. 2006. Plant growthpromoting rhizobacteria. In: Gnanamanickam S. ed. Plantassociated bacteria. Springer, Dordrecht, pp 195-230

Rodriguez, H., Fraga, R. 1999. Phosphate solubilizing bacteria and their role in plant growth promotion. Biotechnol. Adv., 17: 319-339.

Saharan, B.S., Nehra, V. 2011. Plant growth promoting rhizobacteria: a critical review. Life Sci. Med. Res., LSMR-21.

Salimpour, S., Khavazi, K., Nadian, H., Besharati, H., Miransari, M. 2010. Enhancing phosphorous availability to canola. Brassica napus $L$. using $P$ solubilizing and sulfur oxidizing bacteria. Aust. J. Crop Sci., 4: 330 334.

Sanyal, S.K., De Datta, S.K. 1991. Chemistry of phosphorus transformations in soil. Advances in Soil Sci., 16, 1-120.

Saxena, A.K., Tilak, K.V.B.R. 1998. Freeliving nitrogen fixers: its role in crop production. In: Verma AK. ed.
Microbes for health, wealth and sustainable environment. Malhotra Publ Co, New Delhi, pp 25-64

Smith, S.E., Read, D.J. 1997. Mycorrhizal Symbiosis. 2nd ed. Academic Press, London. $605 \mathrm{pp}$.

Ullman, J.B. 1996. Structural equation modeling. In: Using Multivariate Statistics, Third Edition, B.G. Tabachnick and L.S. Fidell, Eds.). HarperCollins College Publishers. New York, NY. pp. 709-819.

Van de Velde, W., Zehirov, G., Szatmari, A., Debreczeny, M., Ishihara, H., Kevei, Z., Farkas, A., Mikulass, K., Nagy, A., Tiricz, H., Satiat-Jeunemaître B, Alunni B, Bourge M, Kucho K-I, Abe M, Kereszt, A., Maroti, G., Uchiumi, T., Kondorosi, E., Mergaert, P. 2010. Plant peptides govern terminal differentiation of bacteria in symbiosis. Sci., 327: 1122-1126.

van Loon, L. 2007. Plant responses to plant growth-promoting rhizobacteria. Eur. J. Plant Pathol., 119: 243-254

Van Peer, R., Van Kiuik, A.J., Rattin, K.H. and Schippers, B. 1990. Control of Fusarium wilt in carnation grown on rockwool by Pseudomonas sp. strain WCS417a and by Fe-EDDA. In: Netherlands J. Plant Pathol., Vol. 96, no. 5; p. 119-132.

Whitelaw, M.A. 2000. Growth promotion of plants inoculated with phosphatesolubilizing fungi. Adv. Agron., 69: 99-151.

\section{How to cite this article:}

Preeti Singh, Seema, S. P. Goswami, Sunita Choudhary and Sunil Kumar. 2017. The Role of Soil Microbes in Plant Nutrient Availability. Int.J.Curr.Microbiol.App.Sci. 6(2): 1444-1449. doi: http://dx.doi.org/10.20546/ijcmas.2017.602.161 